\title{
Exendin-4 enhances expression of Neurod1 and Glut2 in insulin-producing cells derived from mouse embryonic stem cells
}

\author{
Qiaoshi Zhao ${ }^{1}$, Yuzhi Yang ${ }^{2}$, Jing Hư ${ }^{1}$, Zhiyan Shan ${ }^{1}$, Yanshuang Wu' ${ }^{1}$, Lei Lei ${ }^{1}$
}

${ }^{1}$ Department of Histology and Embryology, Harbin Medical University, Harbin, China ${ }^{2}$ Division of Endocrinology, Heilongjiang Provincial Hospital, Harbin, China

Submitted: 11 February 2014

Accepted: 25 March 2014

Arch Med Sci 2016; 12, 1: 199-207

DOI: 10.5114/aoms.2016.57596

Copyright $\odot 2016$ Termedia \& Banach

\section{Abstract}

Introduction: Stem cells involved cell replacement therapies for type 1 diabetes mellitus is promising, yet time-consuming and inefficient. Exendin-4 is a glucagon-like peptide-1 (GLP-1) receptor agonist which has been reported to possess anti-apoptotic effects, thereby increasing $\beta$-cell mass and improving $\beta$-cell function. The present study aimed to investigate whether exendin- 4 would enhance the differentiation of embryonic stem cells into insulin-secreting cells and improve the pancreatic differentiation strategy.

Material and methods: R1 embryonic stem cells were treated with different concentrations of exendin- 4 and divided into three groups. In the high dosage group (group $\mathrm{H}$ ), exendin- 4 was added at the dosage of $10 \mathrm{nmol} / \mathrm{l}$. In the low dosage group (group L), exendin- 4 was added at the dosage of $0.1 \mathrm{nmol} / \mathrm{l}$. Group $C$ was a control. Expression of genes related to the $\beta$-cell phenotype and immunofluorescence staining of insulin and C-peptide were detected.

Results: Compared with groups $\mathrm{L}$ and $\mathrm{C}$, group $\mathrm{H}$ had the highest mRNA expression levels of Is|1, Pdx1, Ngn3, and Insulin1 $(p<0.05)$. Neurod1 and Glut2 only emerged at the final stage of differentiation in group H. Immunofluorescence analysis revealed that exendin-4 upregulated the protein expression of insulin and C-peptide.

Conclusions: Exendin- 4 remarkably facilitated Neurod 1 and Glut2 gene transcription, and was able to induce differentiation of embryonic stem cells into endocrine and insulin-producing cells.

Key words: diabetes, exendin-4, embryonic stem cells, insulin-producing cell.

\section{Introduction}

Embryonic stem (ES) cells are a potential source for regenerative medicine, including cell replacement therapy of diabetes. Over the past few years, several strategies of in vitro generation of insulin-producing cells from ES cells have been accomplished to mimic $\beta$-cell organogenesis. These $\beta$-like cells expressed pancreatic $\beta$-cell-specific markers, secreted insulin in response to glucose, and normalized the hyperglycemic phenotype of streptozotocin (STZ)-induced diabetic mice [1-6]. However, the differentiation strategies above require further optimization for the full maturation of insulin-producing cells.

It is widely accepted that multiple pancreatic transcription factors are involved in pancreas development and $\beta$-cell differentiation. Among these transcription factors, pancreatic duodenal homeobox $1(\mathrm{Pdx} 1)$ is

\author{
Corresponding author: \\ Lei Lei \\ Department of Histology \\ and Embryology \\ Harbin Medical University \\ Xuefu Road 194\# \\ Nangang District Harbin, \\ China \\ Phone: +86-15104581872 \\ E-mail: \\ lei086@ems.hrbmu.edu.cn
}


known both to be required for the development of all kinds of pancreatic cell types and to be a vital regulator of gene expression in mature $\beta$ cells. Pdx1 plays an essential role in pancreas development [7-9], $\beta$-cell differentiation [10, $11]$, regeneration $[12,13]$, and maintenance of function of islet-like clusters [14-18]. Thus, activation of $\mathrm{Pdx} 1$ is considered to be a prerequisite for pancreatic differentiation in vitro, and it should activate a cascade of transcription factors and important $\beta$-cell gene expression including neurogenin 3 (Ngn 3 ), neurogenic differentiation 1 (Neurod1), and glucose transporter 2 (Glut2) within the competent endoderm. Lineage tracking studies show that $\mathrm{Ngn} 3$ is expressed in the endocrine progenitor cells [19]. In addition, targeted disruption in mice suggests that transcription factors, including $P d x 1, N g n 3$, and Neurod1, should be expressed in a correct temporal order for proper lineage specification [20, 21].

Unlike the meglitinide analogues [22], metformin [23], and other oral antidiabetic drugs, exendin-4 (Ex-4) is a synthetic stable glucagon-like peptide-1 (GLP-1) analogue that binds and activates the glucagon-like peptide-1 receptor (GLP-1R) to stimulate glucose-dependent insulin release, and therefore is currently used for the treatment of type 2 diabetes mellitus $[24,25]$. By interacting with Pdx1, GLP-1 agonists are thought to play an important role in improving $\beta$-cell morphology and function [26].

Here, we modified Blyszczuk's published protocol by adding different concentrations of Ex-4 $(0.1 \mathrm{nmol} / \mathrm{l}$ and $10 \mathrm{nmol} / \mathrm{l})$ to induce differentiation of $\beta$ cells from mouse ES cells. We found that high dosage of Ex-4 resulted in higher insulin1 and C-peptide expression. We also investigated the transcript levels of the important signaling factors during differentiation to understand the function of Ex-4 in the formation of insulin-producing cells.

\section{Material and methods}

\section{Maintenance of ES cells}

The mouse R1 ES cell line was purchased from American Type Culture Collection (http://www. atcc.org/). Undifferentiated R1 ES cells were cultured on a feeder layer of mitotically inactivated mouse embryonic fibroblasts with medium containing high-glucose Dulbecco's modified Eagle's medium (DMEM, Hyclone), 15\% fetal bovine serum (FBS, Hyclone), $1 \%$ non-essential amino acids (Invitrogen), $1000 \mathrm{U} / \mathrm{ml}$ mouse recombinant leukemia inhibitory factor (LIF, Millipore), $0.1 \mathrm{mmol} / \mathrm{l}$ 2-mercaptoethanol (Invitrogen), $2 \mathrm{mmol} / \mathrm{l} \mathrm{L-gluta-}$ mine (Invitrogen), $100 \mathrm{U} / \mathrm{ml}$ penicillin and $0.1 \mathrm{mg} /$ $\mathrm{ml}$ streptomycin (Invitrogen). Alkaline phosphatase (AP) staining was performed to evaluate the undifferentiated and pluripotent states of ES cells. Cells were observed and photographed under a phase contrast microscope (Zeiss, LSM700).

\section{In vitro differentiation protocol}

The differentiation of R1 ES cells to the pancreatic lineage was performed based on Blyszczuk's protocol [4] with slight modifications. The differentiation process was carried out in three stages, as shown in Figure 1.

Stage 1: ES medium was changed daily. After $80 \%$ confluence on the third day, ES cells were placed in gelatin-coated culture dishes for two rounds to remove feeder cells. Then $2 \times 10^{6} \mathrm{ES}$ cells were transferred to a $100-\mathrm{mm}$ bacterial Petri dish in medium lacking supplemental LIF (Differentiation medium I, DM I). Resultant embryoid bodies (EBs) remained on the 100-mm dish for 6 days.

Stage 2: EBs suspensions were transferred to a $60-\mathrm{mm}$ tissue-culture plate and allowed to adhere in DM I for 5 days.

Stage 3: After 5 days, the cells were trypsinized and transferred to a plate coated with poly-L-ornithine (PLO) and laminin. For further differentiation and maturation, cells were cultured for 20 days in serum-free Differentiation medium II (DM II) containing DMEM/F-12 (1:1) (Hyclone), 10 mmol/l nicotinamide (Sigma), N2 media supplement (Invitrogen), and ITS media supplement (Sigma) as a control group (group C). At this stage, the protocol diverged into 2 groups. In the high dosage group (group $\mathrm{H}$ ) and low dosage group (group L), Ex-4 was added at the dosage of $10 \mathrm{nmol} / \mathrm{l}$ and

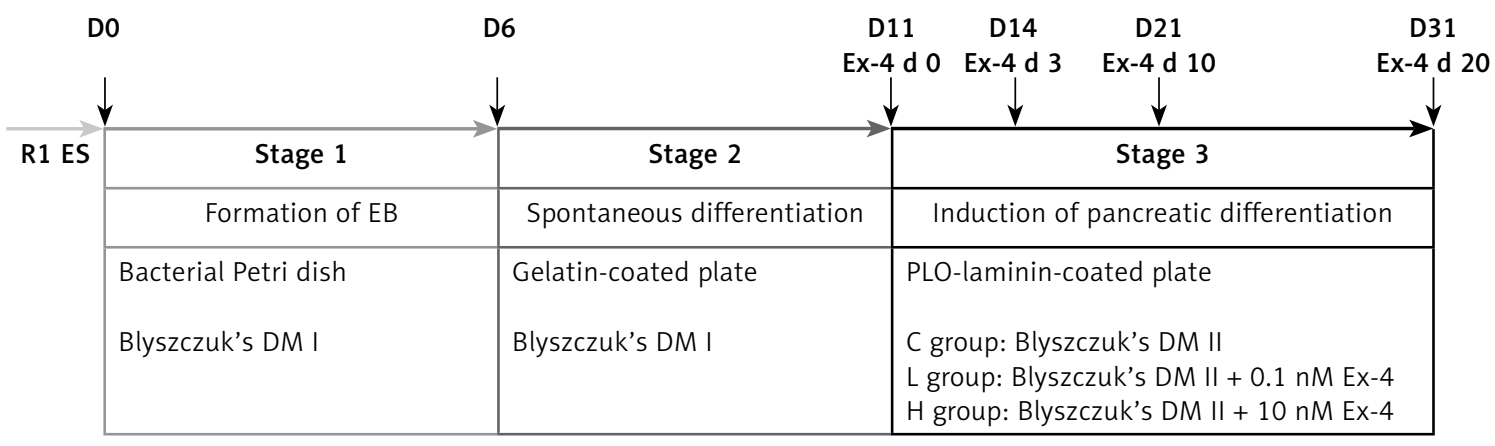

Figure 1. Scheme of the differentiation protocol 
$0.1 \mathrm{nmol} / \mathrm{l}$, respectively. The medium was changed every other day after the cell bodies had attached to the culture dish.

\section{Reverse transcription-polymerase chain reaction}

Total RNA was isolated from undifferentiated R1 ES cells and differentiated R1 ES cells at various stages using an RNeasy mini kit (Qiagen, 74104). Reverse transcription-polymerase chain reaction (RT-PCR) was performed according to the manufacturer's instructions. cDNAs were synthesized using a High Capacity cDNA Reverse Transcription kit (ABI, 4368814). The PCR reactions subjected to 28 and 32 cycles of amplification were performed as follows: $35 \mathrm{~s}$ at $94^{\circ} \mathrm{C}$ for denaturation, $30 \mathrm{~s}$ at individual annealing temperatures for annealing, $30 \mathrm{~s}$ at $72^{\circ} \mathrm{C}$ for elongation. PCR products were separated using $1.5 \%$ agarose gels by electrophoresis and stained with ethidium bromide. The quantities of RNA were estimated according to the intensity of the bands of the PCR products as compared with the intensity of the band corresponding to Gapdh. RT-PCR results were confirmed in three independent experiments. Primer sequences, annealing temperatures and product sizes are summarized in Table I. RT-PCR results were analyzed by ImageJ analyzer system (http:// imagej.nih.gov/ij/).

\section{Immunocytochemistry}

Cell samples were washed three times in PBS and then fixed in $4 \%$ paraformaldehyde (PFA) at $4{ }^{\circ} \mathrm{C}$ for 10 min, permeabilized in $0.5 \%$ Triton $X-100$ for
15 min at room temperature, and blocked with $1 \%$ bovine serum albumin (Sigma, A9418) in PBS at room temperature for $1 \mathrm{~h}$. The cells were incubated with monoclonal anti-insulin antibody (Sigma, FC82291, $1: 200)$ or monoclonal anti-C-peptide antibody (Sigma, WH00007343M1, $1: 200$ ) overnight at $4^{\circ} \mathrm{C}$ followed by Alexa Fluor 488 donkey anti-mouse IgG (Invitrogen, A21202, 1 : 500) incubation at room temperature for $1 \mathrm{~h}$. After the nuclei were stained with Hoechst 33342, the cells were captured under a fluorescent microscope (Zeiss, LSM700).

\section{Statistical analysis}

All experiments were performed in triplicate and the data represent mean \pm SD. Statistical comparisons between different groups were tested by one-way ANOVA. All data were analyzed using SPSS Statistics 19.0. A p-value $<0.05$ (two-sided) is considered as statistically significant.

\section{Results}

\section{Analysis of pluripotency marker expression in R1 ES cells}

It was clear that feeder-present R1 ES cells formed clones with a clear boundary and showed vivid red signals after AP staining, suggesting the undifferentiated and pluripotent state of R1 ES cells (Figures $2 \mathrm{~A}, \mathrm{~B}$ ).

\section{Morphology of differentiated R1 ES cells and insulin-producing cells}

Undifferentiated feeder-free R1 ES cells were cultured in hanging drops and in suspension for

Table I. Sequences of primers, annealing temperatures and product sizes

\begin{tabular}{|c|c|c|c|}
\hline Gene & Primer sequence & $\begin{array}{l}\text { Annealing temperature } \\
{\left[{ }^{\circ} \mathrm{C}\right]}\end{array}$ & $\begin{array}{l}\text { Product size } \\
\quad[\mathrm{bp}]\end{array}$ \\
\hline \multirow[t]{2}{*}{$|s| 1$} & Forward : 5' GTTTGTACGGGATCAAATGC 3' & \multirow[t]{2}{*}{56} & \multirow[t]{2}{*}{503} \\
\hline & Reverse : 5' ATGCTGCGTTTCTTGTCCTT 3' & & \\
\hline \multirow[t]{2}{*}{$\mathrm{Pdx1}$} & Forward : 5' CCACCCCAGTTTACAAGCTC 3' & \multirow[t]{2}{*}{56} & \multirow[t]{2}{*}{315} \\
\hline & Reverse : 5' ACGGGTCCTCTTGTTTTCCT 3' & & \\
\hline \multirow[t]{2}{*}{ Ngn3 } & Forward : 5' TGGCGCCTCATCCCTTGGATG 3' & \multirow[t]{2}{*}{54} & \multirow[t]{2}{*}{245} \\
\hline & Reverse : 5' TCTTCGCTGTTTGCTGAGTG 3' & & \\
\hline \multirow[t]{2}{*}{ Insulin1 } & Forward : 5' TAGTGACCAGCTATAATCAGAGAC 3' & \multirow[t]{2}{*}{56} & \multirow[t]{2}{*}{288} \\
\hline & Reverse : 5' CGCCAAGGTCTGAAGGTC 3' & & \\
\hline \multirow[t]{2}{*}{ Neurod1 } & Forward : 5' CTTGAAGCCATGAATGCAGA 3' & \multirow[t]{2}{*}{56} & \multirow[t]{2}{*}{388} \\
\hline & Reverse : 5' GCGTCTGTACGAAGGAGACC 3' & & \\
\hline \multirow[t]{2}{*}{ Glut2 } & Forward : 5' TTCGGCTATGACATCGGTGTG 3' & \multirow[t]{2}{*}{56} & \multirow[t]{2}{*}{556} \\
\hline & Reverse : 5' AGCTGAGGCCAGCAATCTGAC 3' & & \\
\hline \multirow[t]{2}{*}{ Gapdh } & Forward : 5' TGAAGGTCGGTGTGAACGGAT 3' & \multirow[t]{2}{*}{54} & \multirow[t]{2}{*}{470} \\
\hline & Reverse : 5' CAGGGGGGCTAAGCAGTTGGT 3' & & \\
\hline
\end{tabular}

ISI 1 - ISL1 transcription factor, Pdx1 - pancreatic and duodenal homeobox gene 1, Ngn3 - neurogenin 3, Neurod1 - neurogenic differentiation 1, Glut2-glucose transporter 2, Gapdh-glyceraldehyde-3-phosphate dehydrogenase. 

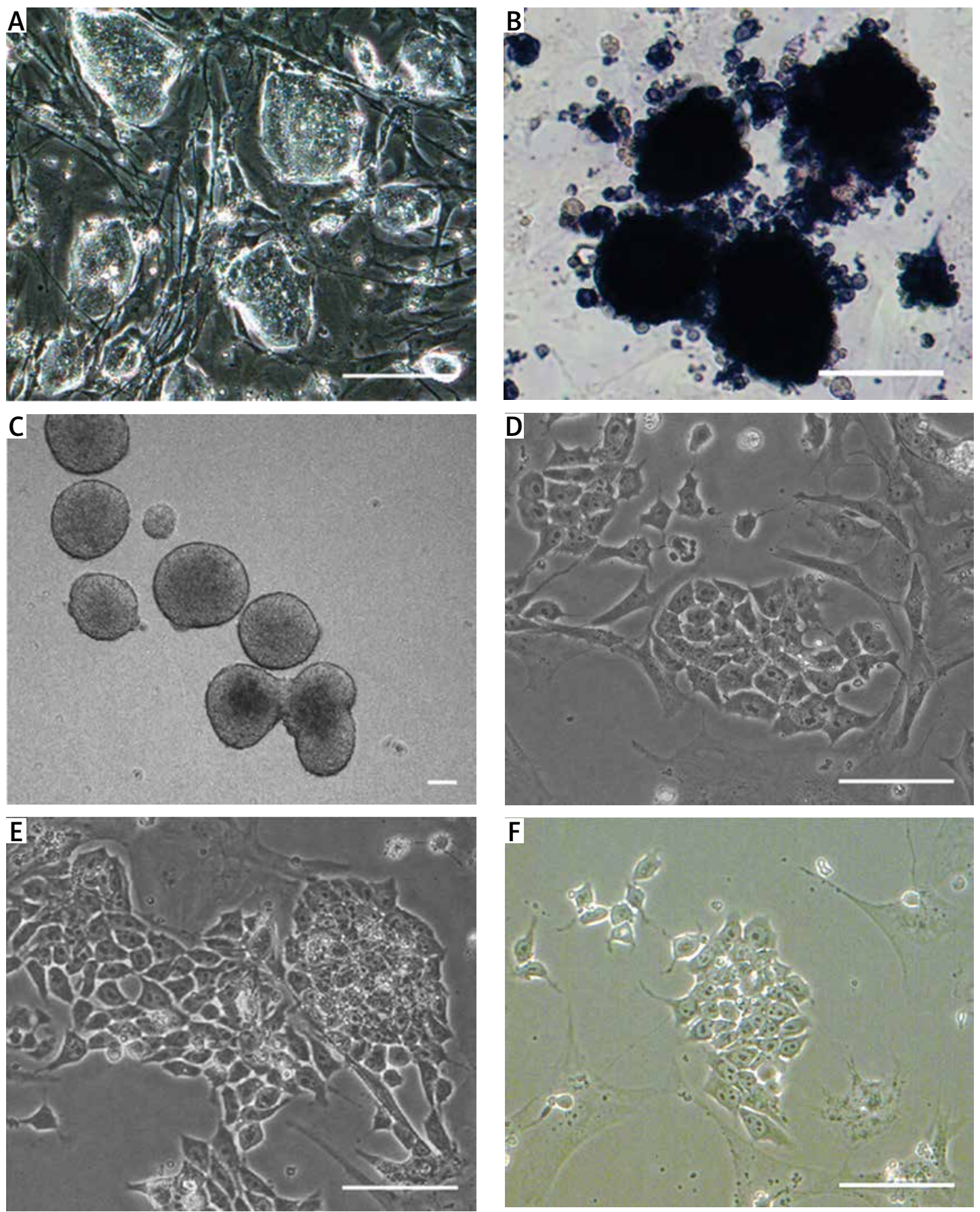

Figure 2. Morphology of RI ES cells, insulin-producing cells derived from different differentiation protocols. A- Morphology of R1 ES cells. B - Alkaline phosphatase (AP) staining of R1 ES cells. C - In vitro formation of simple EBs on day 6 of stage 1 . D-F - Insulin-producing cells derived from different differentiation protocols. D - low dosage group, $\mathbf{E}-$ high dosage group, $\mathbf{F}-$ control group. Scale bars $=25 \mu \mathrm{m}$

$5 \mathrm{~d}$ to form EBs (Figure $2 \mathrm{C}$ ). Then the EBs grew larger and formed into cystic EBs. 6d EBs were plated onto gelatin-coated $60 \mathrm{~mm}$ plates to spontaneously differentiate into multilineage progenitors. In stage 2, a mixed population of epithelial-like and spindle-shaped cells formed around the EBs. EB outgrowths were dissociated and re-seeded onto poly-L-ornithine-laminin-coated culture plates in DM II. The continued cultivation resulted in the formation of insulin-producing cell clusters (Figures 2 D-F).

\section{RT-PCR analysis of expression of genes related to the $\beta$-cell phenotype}

To analyze the stepwise transitions of R1 ES cells during this protocol, total RNA was isolated from differentiated cells treated with Ex-4 in each 
condition for 0 days (Ex-d 0), 3 days (Ex-d 3), 10 days (Ex-d 10) and 20 days (Ex-d 20). RT-PCR for specific genes involved in pancreas development was performed at various stages throughout differentiation (Figures 3 A, B). RNA samples from mouse fetal pancreas were used as a positive control and undifferentiated R1 ES cells were used as a negative control in all the RT-PCR experiments. According to the calibrations and statistical analysis, there was no notable difference among Gapdh product bands for all samples. Endocrine markers such as $I s \mid 1$ and $P d x 1$ were expressed early in stage 3 of differentiation (Figure 3 A). The endocrine progenitor marker gene Ngn3 was also detected at D21 of differentiation, indicating attainment of pancreatic endocrine progenitor stage of the differentiation process (Figure $3 \mathrm{~B}$ ). Is $1, P d x 1, \mathrm{Ngn} 3$, and Insulin 1 relative mRNA expression levels were strikingly higher in group $\mathrm{H}$ compared with groups $L$ and $C$, as shown in Figure $3 \mathrm{D}(p<0.05)$. Fur- thermore, Neurod 1 and the glucose transporter molecule Glut2 only emerged at the final stage of differentiation in group $\mathrm{H}$, suggesting that $\mathrm{R} 1$ ES cells cultured at a higher concentration of Ex-4 were more easily induced to insulin-secreting $\beta$ cells (Figure $3 \mathrm{C}$ ).

\section{Immunofluorescence staining of insulin and C-peptide}

Immunofluorescence analysis of important $\beta$-cell markers was performed to characterize the final stage of R1 ES cell-derived pancreatic differentiation. As shown in Figure 4, a few incompact cell colonies with positive signals for insulin and C-peptide were observed in group C. However, more compact cell colonies from groups $\mathrm{L}$ and $\mathrm{H}$ showed higher expression of insulin and C-peptide (Figures $4 \mathrm{~A}, \mathrm{~B}$ ). At the end of the differentiation procedure, Insulin 1 was indeed detected in these cells, consistent with the result of immuno-
A

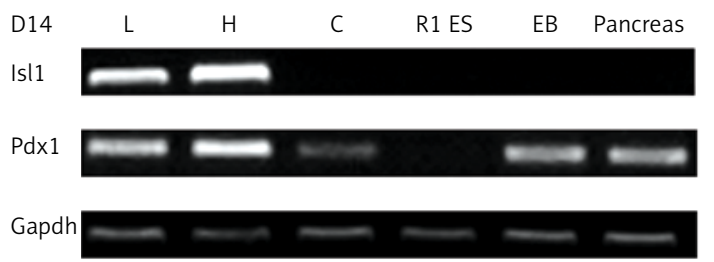

B

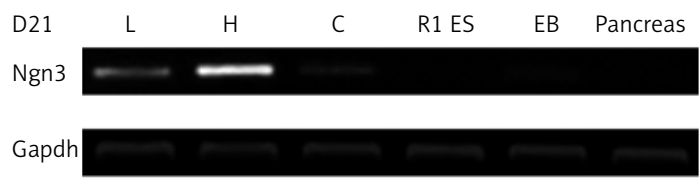

Gapdh

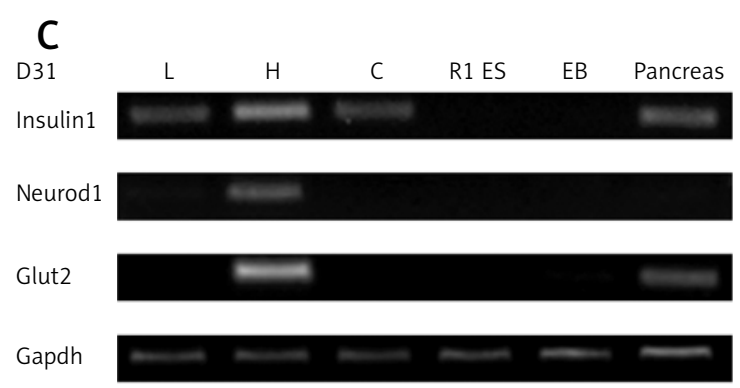

D

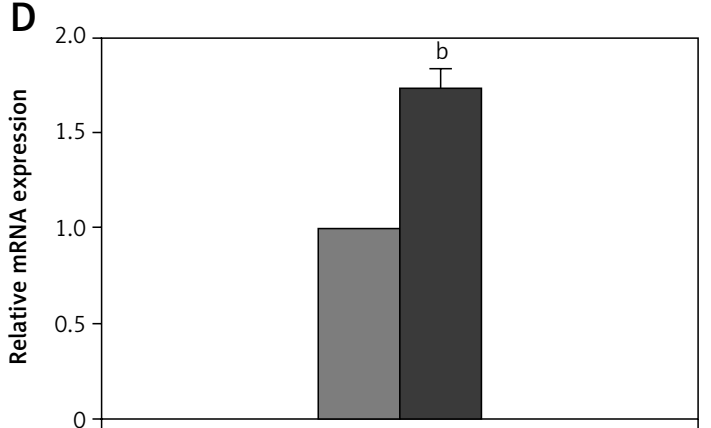

$|s| 1$

$\square \mathrm{L}$

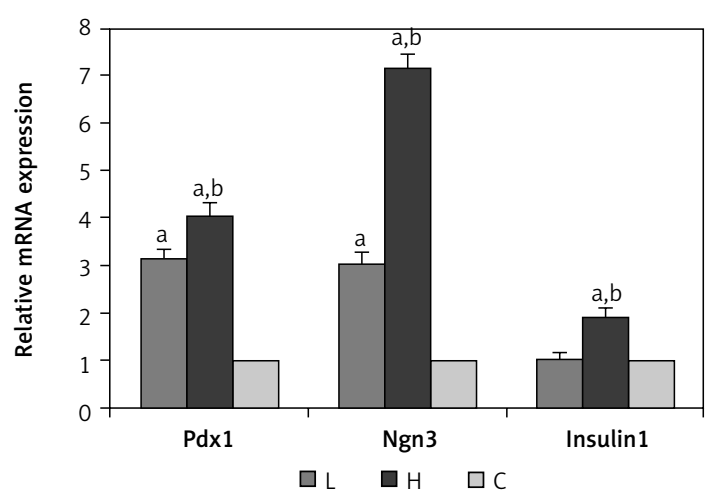

Figure 3. Gene expression profiles of endocrine and late stage pancreas markers in stage 3 cells. Gene expression was assessed at D14 (A), D21 (B), and D31 (C) of differentiation progress. D - Relative mRNA expression of specific genes involved in pancreas development. RT-PCR was performed in triplicate and the data represent mean \pm SD $L$ - low dosage group, $\mathrm{H}$ - high dosage group, $\mathrm{C}$ - control group. ${ }^{a} \mathrm{P}<0.05$ compared to control group, ${ }^{b} p<0.05$ compared to low dosage group. 
fluorescence staining of insulin. As C-peptide is the precursor of mature insulin, it suggested that cells from Ex-4 differentiation groups gained more de novo insulin synthesis (Figure 4 B) [27].

\section{Discussion}

In this research, we modified Blyszczuk's differentiation strategy by adding different concentrations of Ex-4 to study and optimize the differentiation of R1 ES cells into insulin-producing cells. Using immunofluorescence to test expression of insulin and C-peptide, a proof of de novo insulin synthesis, we observed that group $\mathrm{H}$ exhibited a substantially higher signal for staining of insulin and C-peptide than insulin-producing cells generated by groups $L$ and $C$. Thus, the high dosage Ex-4 protocol helped differentiated R1 ES cells to gain a mature pancreatic $\beta$-cell phenotype. Insulin-producing cells derived from groups $H, L$ and $C$ were then subjected to RT-PCR analysis to detect whether they expressed pancreatic hormones and transcription factors including $|s| 1, P d x 1, \mathrm{Ngn} 3$, Insulin1, Neurod1 and Glut2. We demonstrated that expression of endocrine marker genes $I s \mid 1$, $P d x 1$ and $\mathrm{Ngn} 3$ was higher in group H-generated cells compared to group C. Additionally, coexpression of Insulin 1, Neurod1 and Glut2 was only detectable in group $\mathrm{H}$ at the final stage of differentiation. These data together demonstrated that the high dosage Ex-4 protocol formed insulin-producing cells with a more complete pancreatic endocrine molecular signature than that of the other two groups. Apparently, high dosage of Ex-4 triggered selective up-regulation of pancreatic $\beta$-cellspecific genes, which ultimately led to the lineage commitment towards $\beta$ cells.

It can be hypothesized that ectopic expression of Pdx1 enhances the generation of insulin-producing cells, thereby providing large numbers of functional surrogate $\beta$ cells for the treatment of diabetes [28, 29]. Exogenous Pdx1 expression that was precisely regulated by the Tet-off system induced the expression of several pancreatic specific genes, such as Insulin 2, Pax4, Pax6, and $\mathrm{Ngn} 3$, but not the expression of endocrine pancreatic markers Insulin 1, glucagon or Glut2 [30]. The biphasic activation of the Pdx1VP16 transgene in mouse and human ES cells has been demonstrated to promote their differentiation towards the endocrine lineage but to be inhibitory for exocrine development [29]. Recent reports have shown that overexpression of both $P d x 1$ and Ngn 3 motivate many gene expression cascades that mimic embryonic pancreatic development in an appropriate temporal sequence [31]. Although recent studies have achieved high levels of insulin secretion by diverse established protocols, we believe that overexpression of $P d x 1$ or $\mathrm{Ngn} 3$ individually in ES cells may not be sufficient to robustly generate insulin-producing cells. It has been demonstrated that Ex-4 upregulates the expression of $P d x 1$ and $\mathrm{Ngn} 3$ during $\beta$-cell regeneration in STZ-treated mice [32]. Our results suggest that high dosage of Ex-4 may improve the expression of $P d x 1$ and $\mathrm{Ngn} 3$ in vitro differentiation of R1 ES cells to insulin-producing cells.

Neurod 1 is essential for the achievement and maintenance of $\beta$ cell maturation and function $[33,34]$. Stable expression of Neurod 1 in ES cells strongly increased the expression of endocrine transcription factors such as $P d x 1, N k x 6.1, I s \mid 1$ and Glut2, inevitably resulting in the formation of insulin-producing clusters [35]. The highest expression of Neurod 1 in group $\mathrm{H}$ was probably due to the upregulated expression of $\mathrm{Ngn} 3$ stimulated by Ex-4 in our protocol. Our result is in agreement with previous research indicating that Neurod 1 is expressed in a subset of $\mathrm{Ngn}^{+}$endocrine progenitor cells [36]. Also, Neurod 1 acts downstream of $\mathrm{Ngn} 3$ and performs the endocrine differentiation program initiated by $\mathrm{Ngn} 3$ and participates in maintaining the function of mature islet cells $[31,36]$. Taken together, these data suggest that high dosage of Ex-4 facilitates differentiation of R1 ES cells into insulin-producing cells with the help of the following expression of Neurod 1 forced by Ngn3.

GLP-1 stimulates the proliferation of insulin-producing $\beta$-cells and inhibits their apoptosis $[37,38]$. The SLC2A2 gene product GLUT2 is a glucose transporter expressed in the plasma membrane of pancreatic $\beta$ cells, hepatocytes, intestine, and kidney [39]. Transdifferentiation of human pancreatic ductal cells with activin A (ActA) and Ex-4 in high-glucose media resulted in similar expression levels of insulin, PDX1 and GLUT2 compared with normal islets, suggesting that Ex-4 may improve the insulin secretion function of insulin-producing cells by the activation of GLUT2 [40]. Consistent with the latter report that Ex-4 stimulated GLUT2 gene transcription in the INS- 1 pancreatic $\beta$ cell line via the CaMKK/CaMKIV pathway, a significant increase of Glut2 mRNA transcription induced by Ex- 4 was observed in our modified differentiation protocol [41]. Thus, the results that Ex-4 stimulated the expression of Glut2 may lead to mature and glucose-responsive insulin-producing cells derived from ES cells.

In conclusion, we added Ex-4 at different dosages to explore the role Ex-4 played during the differentiation of R1 ES cells towards the mature $\beta$-cell phenotype. The results indicate that $10 \mathrm{nmol} / \mathrm{l}$ Ex-4 may increase the expression of important transcription factors, such as $P d x 1$, Ngn 3, Neurod1 and Glut2, suggesting that Ex-4 is beneficial for $\beta$-cell differentiation from ES cells. Although there is currently no ideal therapy for the treatment of diabetes, it is possible to find 


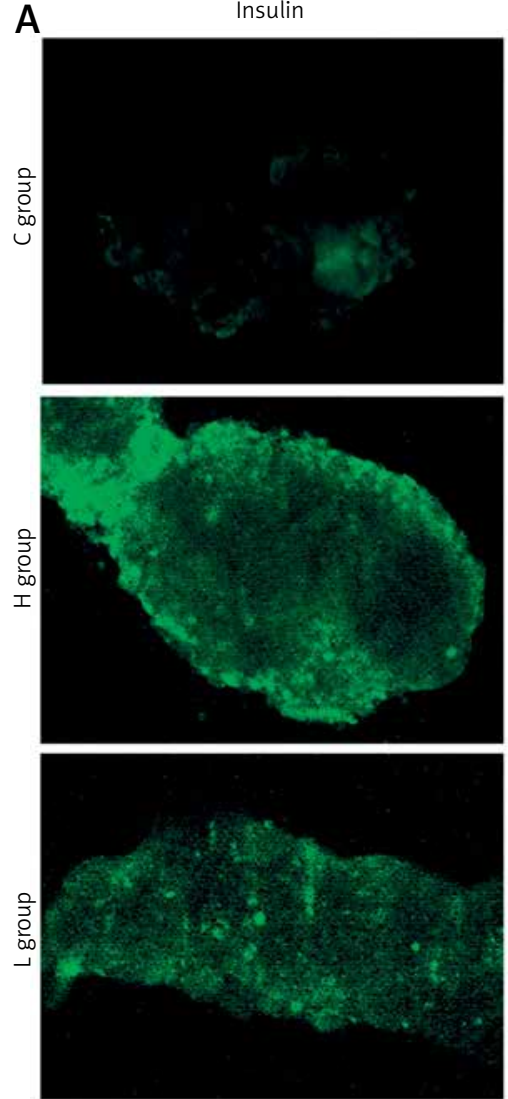

B
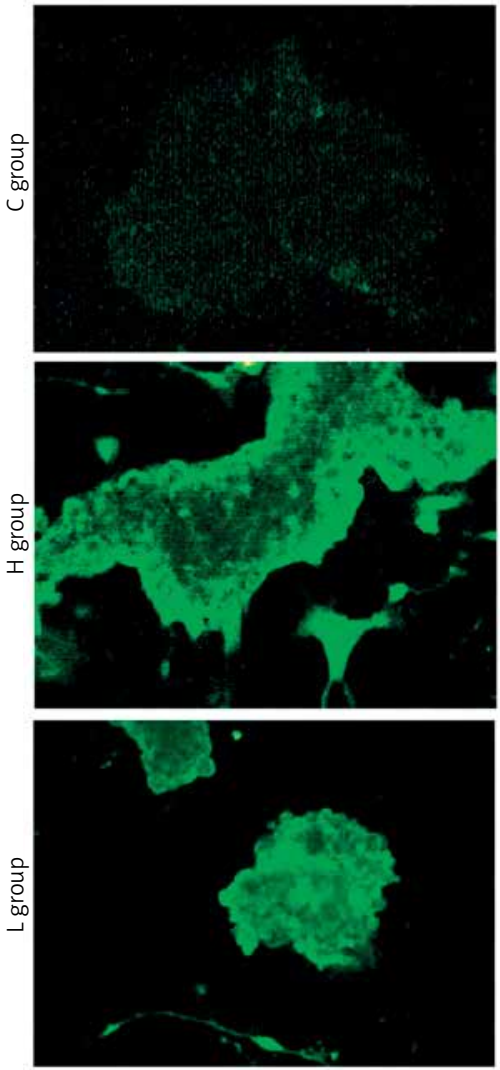

DAPI
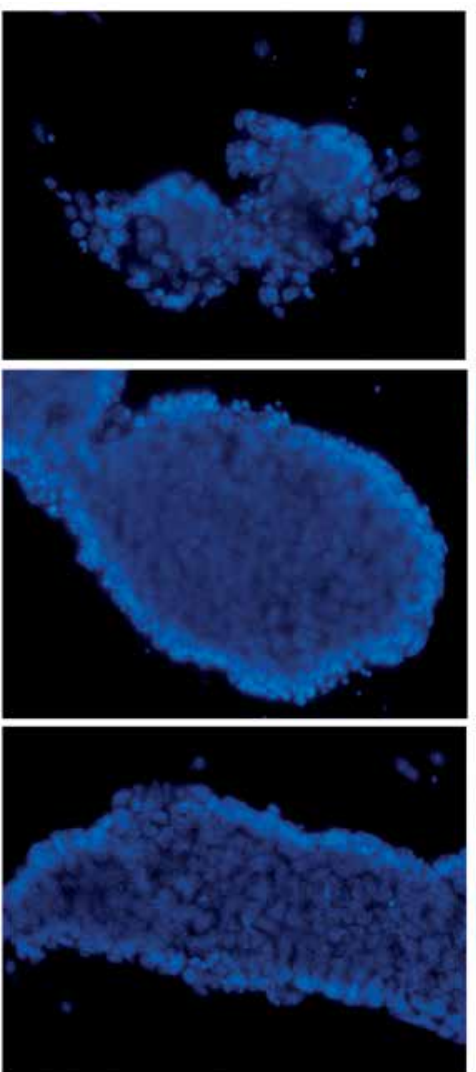

DAPI
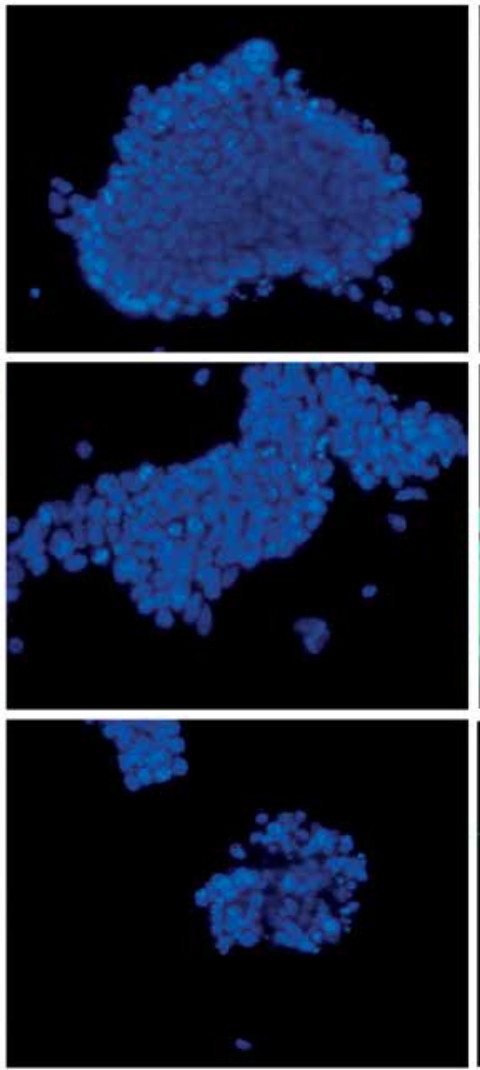

Merge
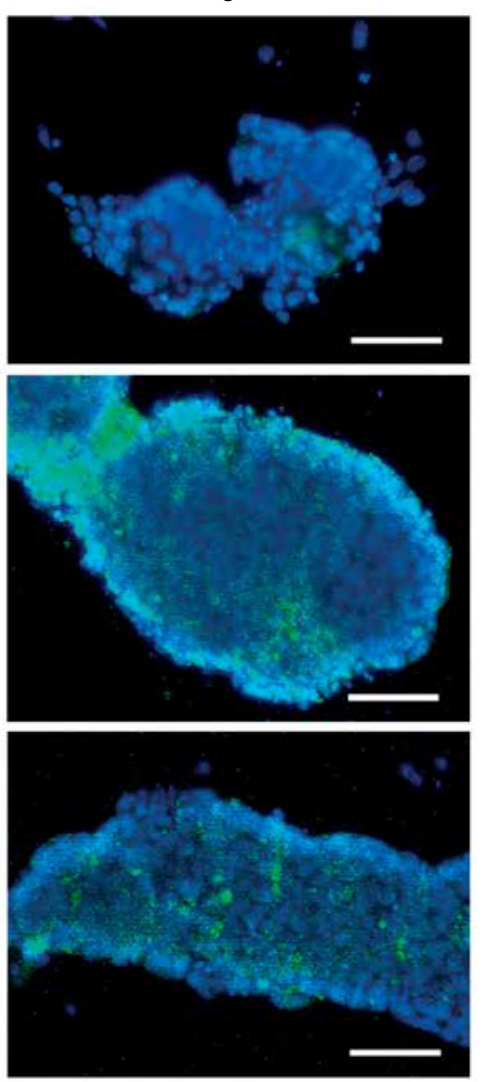

Merge
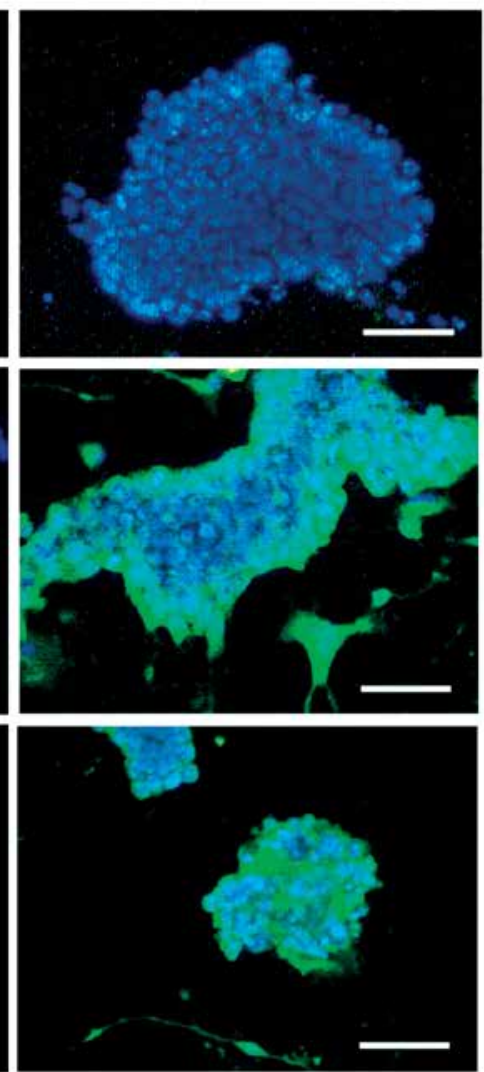

Figure 4. Immunostaining of insulin and C-peptide. Day 31 R1 ES cell-derived insulin-producing cells were immunostained with antibodies against insulin (A) and C-peptide (B). A - Positive signals for insulin were easily observed in groups $C$, $L$ and $\mathrm{H}$. B - C-peptide positive staining was observed only in groups $\mathrm{H}$ and $\mathrm{L}$. Nuclei were stained with DAPI (4',6-diamidine-2'-phenylindole dihydrochloride). Scale bars $=25 \mu \mathrm{m}$ 
a better stem cell-based differentiation strategy that may ultimately provide a cure for diabetes via pancreatic $\beta$-cell replacement.

\section{Acknowledgments}

This work was supported by the National Natural Science Foundation of China (No. 31271590) and Science and Technology Development Programs of Heilongjiang Province (No. GC09C410).

\section{Conflict of interest}

The authors declare no conflict of interest.

\section{References}

1. Soria B, Roche E, Berna G, Leon-Quinto T, Reig JA, Martin F. Insulin-secreting cells derived from embryonic stem cells normalize glycemia in streptozotocin-induced diabetic mice. Diabetes 2000; 49: 157-62.

2. Lumelsky N, Blondel O, Laeng P, Velasco I, Ravin R, MCKay R. Differentiation of embryonic stem cells to in sulin-secreting structures similar to pancreatic islets. Science 2001; 292: 1389-94.

3. Assady S, Maor G, Amit M, Itskovitz-Eldor J, Skorecki KL, Tzukerman M. Insulin production by human embryonic stem cells. Diabetes 2001; 50: 1691-7.

4. Blyszczuk P, Asbrand C, Rozzo A, et al. Embryonic stem cells differentiate into insulin-producing cells without selection of nestin-expressing cells. Int J Develop Biol 2004; 48: 1095-104.

5. D'Amour KA, Bang AG, Eliazer S, et al. Production of pancreatic hormone-expressing endocrine cells from human embryonic stem cells. Nature Biotechnol 2006; 24: 1392-401.

6. Kroon E, Martinson LA, Kadoya K, et al. Pancreatic endoderm derived from human embryonic stem cells generates glucose-responsive insulin-secreting cells in vivo. Nature Biotechnol 2008; 26: 443-52.

7. Jonsson J, Carlsson L, Edlund T, Edlund H. Insulin-promoter-factor 1 is required for pancreas development in mice. Nature 1994; 371: 606-9.

8. Offield MF, Jetton TL, Labosky PA, et al. PDX-1 is required for pancreatic outgrowth and differentiation of the rostral duodenum. Development 1996; 122: 983-95.

9. Holland AM, Hale MA, Kagami H, Hammer RE, MacDonald RJ. Experimental control of pancreatic development and maintenance. Proc Natl Acad Sci USA 2002; 99: 12236-41.

10. Kaneto H, Nakatani Y, Miyatsuka T, et al. PDX-1/VP16 fusion protein, together with NeuroD or Ngn3, markedly induces insulin gene transcription and ameliorates glucose tolerance. Diabetes 2005; 54: 1009-22.

11. Miyatsuka T, Kaneto H, Kajimoto Y, et al. Ectopically expressed PDX-1 in liver initiates endocrine and exocrine pancreas differentiation but causes dysmorphogenesis. Biochem Biophys Res Com 2003; 310: 1017-25.

12. Sharma A, Zangen DH, Reitz P, et al. The homeodomain protein IDX-1 increases after an early burst of proliferation during pancreatic regeneration. Diabetes 1999; 48: 507-13.

13. Holland AM, Gonez LJ, Naselli G, Macdonald RJ, Harrison LC. Conditional expression demonstrates the role of the homeodomain transcription factor Pdx1 in maintenance and regeneration of beta-cells in the adult pancreas. Diabetes 2005; 54: 2586-95.
14. Kushner JA, Ye J, Schubert M, et al. Pdx1 restores beta cell function in Irs2 knockout mice. J Clin Investig 2002; 109: 1193-201.

15. Brissova M, Shiota M, Nicholson WE, et al. Reduction in pancreatic transcription factor PDX-1 impairs glucose-stimulated insulin secretion. J Biol Chem 2002; 277: 11225-32.

16. Kulkarni RN, Jhala US, Winnay JN, Krajewski S, Montminy M, Kahn CR. PDX-1 haploinsufficiency limits the compensatory islet hyperplasia that occurs in response to insulin resistance. J Clin Investig 2004; 114: 828-36.

17. Oliver-Krasinski JM, Kasner MT, Yang J, et al. The diabetes gene $\mathrm{Pdx} 1$ regulates the transcriptional network of pancreatic endocrine progenitor cells in mice. J Clin Investig 2009; 119: 1888-98.

18. Yasuda A, Sawai H, Ochi N, Matsuo Y, Okada Y, Takeyama H. Solid variant of serous cystadenoma of the pancreas. Arch Med Sci 2011; 7: 353-5.

19. Gu G, Dubauskaite J, Melton DA. Direct evidence for the pancreatic lineage: NGN3+ cells are islet progenitors and are distinct from duct progenitors. Development 2002; 129: 2447-57.

20. Naya FJ, Huang HP, Qiu Y, et al. Diabetes, defective pancreatic morphogenesis, and abnormal enteroendocrine differentiation in BETA2/neuroD-deficient mice. Genes Develop 1997; 11: 2323-34.

21. Lima MJ, Docherty HM, Chen Y, Vallier L, Docherty K. Pancreatic transcription factors containing protein transduction domains drive mouse embryonic stem cells towards endocrine pancreas. PloS One 2012; 7: e36481.

22. Guardado-Mendoza R, Prioletta A, Jimenez-Ceja LM, Sosale A, Folli $F$. The role of nateglinide and repaglinide, derivatives of meglitinide, in the treatment of type 2 diabetes mellitus. Arch Med Sci 2013; 9: 936-43.

23. Cicero AF, Tartagni E, Ertek S. Metformin and its clinical use: new insights for an old drug in clinical practice. Arch Med Sci 2012; 8: 907-17.

24. Kolterman OG, Kim DD, Shen L, et al. Pharmacokinetics, pharmacodynamics, and safety of exenatide in patients with type 2 diabetes mellitus. Am J Health Sys Pharm 2005; 62: 173-81.

25. Papaetis GS, Papakyriakou P, Panagiotou TN. Central obesity, type 2 diabetes and insulin: exploring a pathway full of thorns. Arch Med Sci 2015; 11: 463-82.

26. Bonora E. Protection of pancreatic beta-cells: is it feasible? Nutr Metab Cardiovasc Dis 2008; 18: 74-83.

27. Szepietowska B, Glebocka A, Puch U, Gorska M, Szelachowska M. Latent autoimmune diabetes in adults in a population-based cohort of Polish patients with newly diagnosed diabetes mellitus. Arch Med Sci 2012; 8: 491-5.

28. Koya V, Lu S, Sun YP, et al. Reversal of streptozotocin-induced diabetes in mice by cellular transduction with recombinant pancreatic transcription factor pancreatic duodenal homeobox-1: a novel protein transduction domain-based therapy. Diabetes 2008; 57: 757-69.

29. Bernardo AS, Cho CH, Mason S, et al. Biphasic induction of Pdx1 in mouse and human embryonic stem cells can mimic development of pancreatic beta-cells. Stem Cells 2009; 27: 341-51.

30. Miyazaki S, Yamato E, Miyazaki J. Regulated expression of pdx-1 promotes in vitro differentiation of insulin-producing cells from embryonic stem cells. Diabetes 2004; 53: 1030-7.

31. Kubo A, Stull R, Takeuchi M, et al. Pdx1 and Ngn3 overexpression enhances pancreatic differentiation of 
mouse ES cell-derived endoderm population. PloS One 2011; 6: e24058.

32. Kodama S, Toyonaga T, Kondo T, et al. Enhanced expres sion of PDX-1 and Ngn3 by exendin-4 during beta cell regeneration in STZ-treated mice. Biochem Biophys Res Com 2005; 327: 1170-8.

33. Qiu Y, Guo M, Huang S, Stein R. Insulin gene transcription is mediated by interactions between the p300 coactivator and PDX-1, BETA2, and E47. Mol Cell Biol 2002; 22: 412-20.

34. Gu C, Stein GH, Pan N, et al. Pancreatic beta cells require NeuroD to achieve and maintain functional maturity Cell Metabol 2010; 11: 298-310.

35. Marchand M, Schroeder IS, Markossian S, et al. Mouse ES cells over-expressing the transcription factor $\mathrm{Neu}$ roD1 show increased differentiation towards endocrine lineages and insulin-expressing cells. Int I Develop Biol 2009; 53: 569-78

36. Mastracci TL, Anderson KR, Papizan JB, Sussel L. Regulation of Neurod 1 contributes to the lineage potential of Neurogenin3+ endocrine precursor cells in the pancreas. PLoS Genet 2013; 9: e1003278.

37. Drucker DJ, Nauck MA. The incretin system: glucagon-like peptide-1 receptor agonists and dipeptidyl peptidase-4 inhibitors in type 2 diabetes. Lancet 2006; 368: 1696-705.

38. Egan JM, Bulotta A, Hui H, Perfetti R. GLP-1 receptor agonists are growth and differentiation factors for pancreatic islet beta cells. Diabetes Metabol Res Rev 2003; 19: 115-23.

39. Leturque A, Brot-Laroche E, Le Gall M. GLUT2 mutations, translocation, and receptor function in diet sugar managing. Am J Physiol Endocrinol Metabol 2009; 296: E985-92.

40. Kim HS, Hong SH, Oh SH, Kim JH, Lee MS, Lee MK. Activin $\mathrm{A}$, exendin-4, and glucose stimulate differentiation of human pancreatic ductal cells. J Endocrinol 2013; 217 241-52.

41. Chen K, Yu X, Murao K, et al. Exendin-4 regulates GLUT2 expression via the CaMKK/CaMKIV pathway in a pancreatic beta-cell line. Metabol Clin Exp 2011; 60: 579-85. 